\title{
Corrigendum: The Effects of Framework Mutations at the Variable Domain Interface on Antibody Affinity Maturation in an HIV-1 Broadly Neutralizing Antibody Lineage
}

\author{
Jeffrey O. Zhou ${ }^{1}$, Hussain A. Zaidi ${ }^{1}$, Therese Ton $^{2}$ and Daniela Fera ${ }^{1 *}$ \\ ${ }^{1}$ Department of Chemistry and Biochemistry, Swarthmore College, Swarthmore, PA, United States, ${ }^{2}$ Department of Biology, \\ Swarthmore College, Swarthmore, PA, United States
}

Keywords: human immunodeficiency virus, antibody, evolution, crystal structure, somatic hypermutation, framework

\section{A Corrigendum on}

OPEN ACCESS

Approved by:

Frontiers Editorial Office,

Frontiers Media SA, Switzerland

*Correspondence:

Daniela Fera

dfera1@swarthmore.edu

Specialty section:

This article was submitted to

Viral Immunology,

a section of the journal

Frontiers in Immunology

Received: 23 October 2020

Accepted: 26 October 2020

Published: 18 November 2020

Citation:

Zhou JO, Zaidi HA, Ton T and Fera D (2020) Corrigendum: The Effects of Framework Mutations at the Variable Domain Interface on Antibody Affinity Maturation in an HIV-1 Broadly Neutralizing Antibody Lineage.

Front. Immunol. 11:620518. doi: 10.3389/fimmu.2020.620518
The Effects of Framework Mutations at the Variable Domain Interface on Antibody Affinity Maturation in an HIV-1 Broadly Neutralizing Antibody Lineage

by Zhou JO, Zaidi HA, Ton T, Fera D, (2020). Front Immunol. 11:1529. doi: 10.3389/fimmu.2020.01529

In the original article, we neglected to include the funder NIGMS from the NIH, P30 GM124165 to NECAT beamlines; the funder NIH-ORIP HEI, S10OD021527 to the Eiger 16M detector on the 24-ID-E beam line; and the funder US DOE, DE-AC02-06CH11357 to APS. The corrected funding section appears below:

JZ was supported by the Meyer Davidson '57 Summer Research Fellowship Grant. DF acknowledges support from the Mathilde Krim Fellowship in Basic Biomedical Research (109502-61-RKVA) from amfAR and Swarthmore College Startup and Faculty Research Funds. This work is based upon research conducted at NE-CAT beamlines, which are funded by the NIGMS from the NIH (P30 GM124165). The Eiger 16M detector on the 24-ID-E beam line is funded by a NIH-ORIP HEI grant (S10OD021527). This research used resources of the Advanced Photon Source, a U.S. Department of Energy (DOE) Office of Science User Facility operated for the DOE Office of Science by Argonne National Laboratory under Contract No. DE-AC02-06CH11357.

The authors apologize for this error and state that this does not change the scientific conclusions of the article in any way. The original article has been updated.

Copyright $\odot 2020$ Zhou, Zaidi, Ton and Fera. This is an open-access article distributed under the terms of the Creative Commons Attribution License (CC BY). The use, distribution or reproduction in other forums is permitted, provided the original author(s) and the copyright owner(s) are credited and that the original publication in this journal is cited, in accordance with accepted academic practice. No use, distribution or reproduction is permitted which does not comply with these terms. 